\title{
MOLEKUL
}

Articles

www.jmolekul.com

https://doi.org/10.20884/1.jm.2020.15.3.654

\section{Cation Sensing Capabilities of A Nitrophenyl Cinnamaldehyde Derivative}

\author{
Venty Suryanti ${ }^{1,}$, Fajar Rakhman Wibowo', Ahmad Marzuki ${ }^{2}$, Meiyanti Ratna Kumala Sari ${ }^{1}$ \\ 'Department of Chemistry, Faculty of Mathematics and Natural Sciences, Sebelas Maret University, JI. Ir. Sutami \\ 36A Surakarta 57126, Indonesia \\ ${ }^{2}$ Department of Physics, Faculty of Mathematics and Natural Sciences, Sebelas Maret University, Jl. Ir. Sutami \\ 36A Surakarta 57126, Indonesia
}

*Corresponding author email: venty@mipa.uns.ac.id

Received April 12, 2020; Accepted September 08, 2020; Available online November 20, 2020

\begin{abstract}
The cationic chemosensor based on organic compound bearing an aminophenol moiety as a receptor for metal analyte and a cinnamaldehyde moiety as chromophoric fragment has been developed. In this work, we report the colorimetric sensing of nitrophenyl cinnamaldehyde derivative, namely methyl-3-(2-hidroxy-5-nitrophenyl amino)-3-phenylpropanoate, towards a variety of metal cations, such as $\mathrm{Cu}^{2+}, \mathrm{Fe}^{3+}, \mathrm{Ni}^{2+}$ and $\mathrm{Zn}^{2+}$. The cation sensing abilities of the sensor were observed for $\mathrm{Cu}^{2+}$ and $\mathrm{Fe}^{3+}$ with a color change from colorless to pink and faint yellow, respectively, The characteristic UV-Vis spectra changes were observed upon addition of $\mathrm{Cu}^{2+}$ and $\mathrm{Fe}^{3+}$ cations. The hypsochromic absorption spectra shifts were obtained, indicating the cations and sensor complexations had formed. A metal-to-ligand-charge-transfer (MLCT) had occurred and the charge density of the sensor changed resulting in appearance of new absorption peaks in the UV-Vis spectra and color changes of the sensor solution upon addition of the $\mathrm{Cu}^{2+}$ and $\mathrm{Fe}^{3+}$.
\end{abstract}

Keywords: cation sensor; chemosensor, chromophoric fragment; cinnamaldehyde derivative

\section{INTRODUCTION}

Cations play many important roles in biological and chemical processes in human life. However, excessive cation concentration level has a negative impact on environment and human health. The amount of cation on the environment need to be control to minimize their negative impacts (Ali, Khan, \& llahi 2019; Tchounwou et al., 2012; Jaishankar et al., 2014). Various analytical methods have been used for cation detections such as titrimetry, potentiometry, flame atomic emission spectrometry, atomic absorption spectroscopy and ion selective electrodes. However, these methods are expensive and in-efficient because they require a lot of samples and special treatment during preparation (Bansod et al., 2017; Dalmieda \& Kruse, 2019; Hyalii, Bhagure \& Chavan, 2017; Kumar et al., 2017; March, Nguyen, \& Piro, 2015; Topcu et al., 2018). A low-cost and efficient ion monitoring and measuring can be carried out using colorimetric cation chemosensors (Aderinto \& Imhanria, 2018; Chen et al., 2020; Kaur \& Kumar, 2011; Normaya et al., 2019; Pham et al., 2019; Upadhyay et al., 2019; Wang, Fang \& Cao, 2015).
A cation chemosensor requires receptor unit and/or ligand which is able to donate electron pairs for forming coordination covalent bond with cations (Aderinto \& Imhanria, 2018; Chen et al., 2020; Kaur \& Kumar, 2011; Normaya et al., 2019; Pham et al., 2019; Upadhyay et al., 2019; Wang, Fang, \& Cao, 2015). A chemosensor also has need to have an electron withdrawal group as a chromogenic signaling unit. Interactions between sensor and ion produce color changes that can be detected visually. The color change affects the shift of the absorbance peak in the UV-Vis region (Suryanti et al., 2014; Suryanti et al., 2017).

The cation chemosensors synthesized from natural compounds as a starting materials are still limited. Cinnamaldehyde is a potential starting material for synthesizing of cation chemosensors. Compound 4chloro-2-[(3-(4-(dimethylamino) phenyl)allyldene)amino]phenol, a cinnamaldehyde derivative, has been recognized as a colorimetric $\mathrm{Ni}^{2+}$ sensor in aqueous solution (Peralta-Domínguez et al., 2015). Another cynnamaldehyde derivative, 3-methyl-(2hydroxy-5-nitrophenylamino)-3-phenylpropanoate (1) 
<smiles>COC(=O)CC(Nc1cc([N+](=O)[O-])ccc1O)c1ccccc1</smiles>

Figure 1. Structure of 3-methyl-(2-hydroxy-5nitrophenylamino)-3-phenylpropanoate (1).

(Figure 1), was synthesized from cinnamaldehyde through 4 step reactions (Suryanti, Wibowo, Pranoto, Isnaeni, Sari \& Handayani, 2016).

Compound 1 has been recognized as a chemosensor for oxyanions, such as $\mathrm{H}_{2} \mathrm{PO}_{4}^{-}$and $\mathrm{AcO}^{-}$. In compound 1, the hydrogens of $\mathrm{NH}$ and $\mathrm{OH}$ groups form hydrogen bonds with anions, whereas the nitrophenyl group acts as chromogenic signaling unit (Suryanti, Wibowo, \& Handayani, 2020). Besides, compound 1 possesses lone pair electrons on $\mathrm{N}$ and $\mathrm{O}$ atoms of the $\mathrm{NH}$ and $\mathrm{OH}$ groups, respectively, which have possibility in forming coordinate covalent bonds with cations. Therefore, compound 1 was expected to act as a chromogenic cation sensor. In this work, we report the colorimetric sensing of compound 1 towards a variety of cations, such as $\mathrm{Fe}^{3+}, \mathrm{Cu}^{2}, \mathrm{Ni}^{2+}$ and $\mathrm{Zn}^{2+}$.

\section{EXPERIMENTAL SECTION}

\section{Materials}

All cations in the form of nitrate salts were purchased from Merck (Darmstadt, Germany) and used without further purification. All solvents employed were of analytical grade and also used without further purification.

\section{Synthesis of Compound 1}

Compound 1 was synthesized from cinnamaldehyde following a previously reported procedures (Suryanti et al., 2016). The steps included oxidation reaction of cinnamaldehyde, which was followed by esterification of the acid. The final step was the reaction between the ester and 2-amino-4-nitrophenol to yield the final products, namely methyl-3-(2-hidroxy-5-nitrophenyl amino)-3-phenylpropanoate (compound 1).

\section{Cation Binding Studies}

Solution $1\left(1 \times 10^{-5} \mathrm{M}\right)$ was dissolved in acetone. Stock solutions of metal cation with concentration of $1 \mathrm{x}$ $10^{-3} \mathrm{M}$ were prepared by dissolving $\mathrm{Fe}\left(\mathrm{NO}_{3}\right)_{3} .9 \mathrm{H}_{2} \mathrm{O}$, $\mathrm{Cu}\left(\mathrm{NO}_{3}\right)_{2} .4 \mathrm{H}_{2} \mathrm{O}, \mathrm{Ni}\left(\mathrm{NO}_{3}\right)_{2} .6 \mathrm{H}_{2} \mathrm{O}$ or $\mathrm{Zn}\left(\mathrm{NO}_{3}\right)_{2}$ in distilled water at $\mathrm{pH} 7$. Sensing properties were evaluated by mixing a few microliter of the metal cations stock solution to a known volume of the compound 1 solution $(2 \mathrm{ml})$. The total volume of the addition metal cations solution was limited to $0.1 \mathrm{ml}$, so that the dilution of the compound 1 solution remained insignificant. The colorimetric performance was evaluated by naked eye and quantified by UV-Vis absorption spectroscopy. Absorption spectra were examined in the wavelength interval 280-650 nm. The UV-Vis Shimadzu Lambda 25 spectrophometer was used at room temperature for obtaining the UV-Vis spectra.

\section{RESULTS AND DISCUSSION \\ Visual Observation of Compound 1 in the Presence of Cations}

The colorimetric properties of compound 1 were examined by the addition of various cations such as $\mathrm{Fe}^{3+}, \mathrm{Cu}^{2+}, \mathrm{Ni}^{2+}$ and $\mathrm{Zn}^{2+}$ in acetone. The addition of 4 eq $\mathrm{Fe}^{3+}$ into compound $1\left(1 \times 10^{-5} \mathrm{M}\right)$ gave a color change from colorless to yellowish while the presence of 4 eq $\mathrm{Cu}^{2+}$ caused a color change from colorless to pink. However, the addition of 4 eq $\mathrm{Ni}^{2+}$ and $\mathrm{Zn}^{2+}$ did not result in a color change of the solution 1. The color changes of solution 1 after addition of cations were shown in Figure 2. The color changes of solution 1 was further investigated by stepwise addition of $\mathrm{Fe}^{3+}$ and $\mathrm{Cu}^{2+}$. The naked-eye color changes of solution 1 was detectable upon addition of $1.5 \mathrm{eq} \mathrm{Fe}^{3+}$ or $1.5 \mathrm{eq} \mathrm{Cu}^{2+}$. The coloration of the solution was intensified with increasing anions concentration (Figure 3).

\section{UV-Vis Spectroscopy Analysis of Compound 1 in the Presence of Cations}

Interactions between $\mathrm{Fe}^{3+}, \mathrm{Cu}^{2+}, \mathrm{Ni}^{2+}$ or $\mathrm{Zn}^{2+}$ with compound 1 were investigated through UV-Vis spectrophotometer. Preliminary studies were carried out by addition of 4 eq of cation to solution 1 in acetone. A cation which interacts with compound 1 causes shifting of the absorbance peaks. Spectra changes of compound 1 on the presence of cations is presented in Figure 4. The addition of $\mathrm{Fe}^{3+}$ or $\mathrm{Cu}^{2+}$ produced significant changes of the spectra, including shifting and increasing of absorbance. However, the addition of $\mathrm{Zn}^{2+}$ or $\mathrm{Ni}^{2+}$ only increase the absorbance intensity.

UV-Vis spectroscopy analysis was further carried out by the stepwise addition of $\mathrm{Fe}^{3+}$ or $\mathrm{Cu}^{2+}$ (0-4 eq) into solution $1\left(1 \times 10^{-5} \mathrm{M}\right)$. UV-Vis spectra show that increasing amount of $\mathrm{Fe}^{3+}$ causes peak shifting at 379 to $361 \mathrm{~nm}$ and decreasing shoulder at 410-540 $\mathrm{nm}$, gradually (Figure 5). This new absorption peak appeared upon addition of 1.5 eq. of $\mathrm{Fe}^{3+}$ and the further addition of $\mathrm{Fe}^{3+}$ ion did not change the absorbance spectra. These spectral characteristics were also accompanied by a visual color change of the solution from colorless to faint yellow upon addition of $\mathrm{Fe}^{3+}$. 


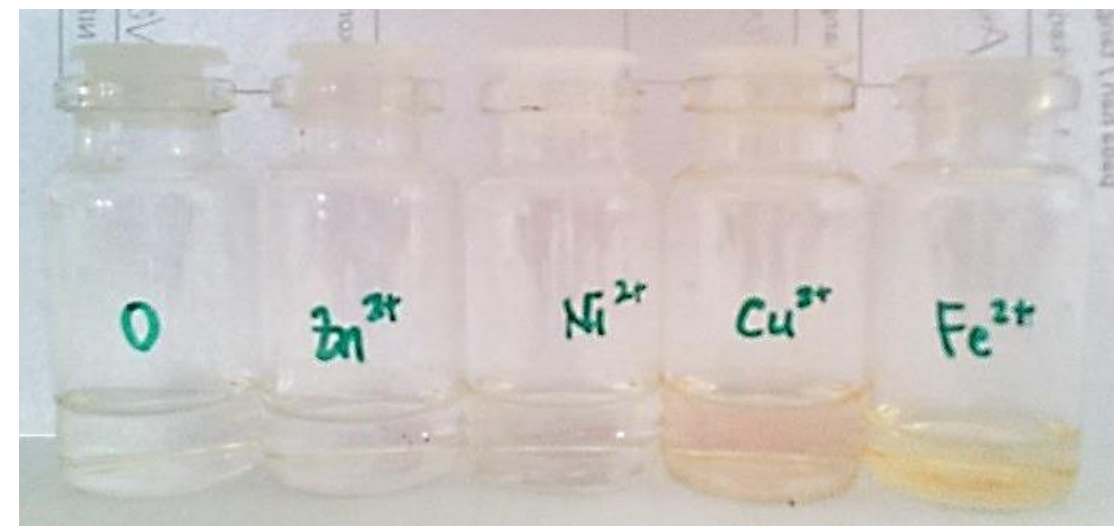

Figure 2. The color changes of compound 1 in acetone was observed upon addition of 4 eq. of various cations, such as $\mathrm{Zn}^{2+}, \mathrm{Ni}^{2+}, \mathrm{Cu}^{2+}$ and $\mathrm{Fe}^{3+}$.

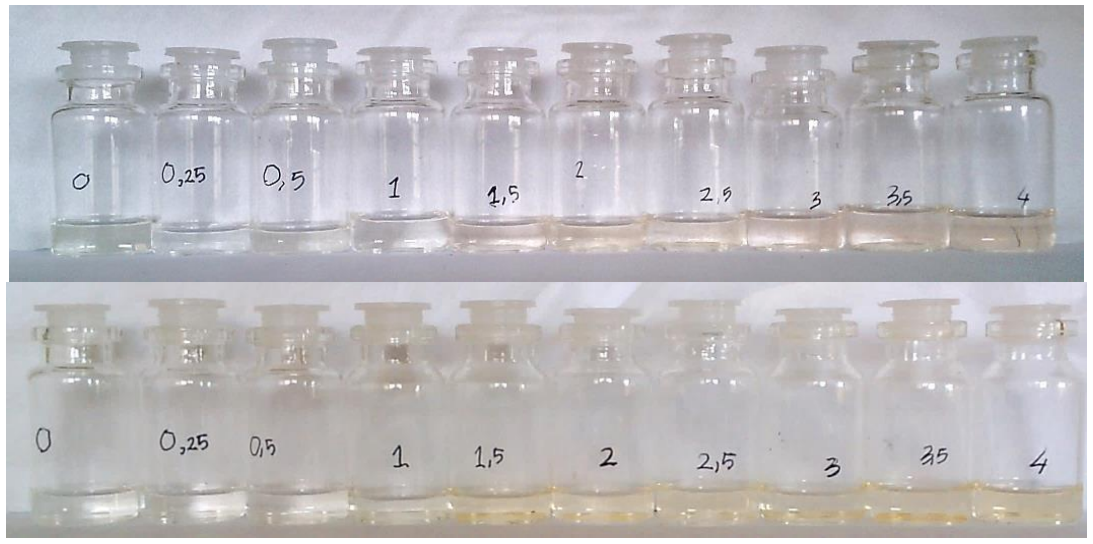

Figure 3. The color changes of compound 1 in acetone was observed upon addition of the cations as nitrate salts: $\mathrm{Cu}^{2+}$ (upper) and $\mathrm{Fe}^{3+}$ (lower).

The phenomenon occurring in these experiments were similar to some compounds which act as cation sensors for $\mathrm{Fe}^{3+}$. Compound 1,1'-((1E, 1'E)-((thiobis(ethane-2,1-diyl))bis(azanylylidene))bis(met hanylylidene))bis(naphthalen-2-ol) gives absorbance at $400 \mathrm{~nm}$, while its interaction with $\mathrm{Fe}^{3+}$ forms a peak at $600 \mathrm{~nm}$ and changes color from colorless to pale purple (Lee, Yang, \& Kim, 2018). Naphthalene diimide amphiphile (NDI-A) based compounds give absorbance at $350 \mathrm{~nm}, 380 \mathrm{~nm}$ and $430 \mathrm{~nm}$, while its interaction with $\mathrm{Fe}^{3+}$ formed spectra with a significant decrease in intensity at the wavelength section of $430 \mathrm{~nm}$ and changing the color from yellow to colorless (Ghule, Bhosale, Puyad, \& Bhosale, 2016). The cation $\mathrm{Fe}^{3+}$ in this case removes the color from the receptor. Borondipyrromethene (BODIPY) based compounds with phenols as binding sites forms absorbance at $534 \mathrm{~nm}$ and $571 \mathrm{~nm}$, while interactions with $\mathrm{Fe}^{3+}$ formed a wavelength at $502 \mathrm{~nm}$, changing color from pink to yellow (Wang, Fang, \& Cao, 2015).
The addition of $\mathrm{Cu}^{2+}$ results in peak shifting from 379 to $366 \mathrm{~nm}$ and increasing in absorption intensity at 460 $550 \mathrm{~nm}$, gradually (Figure 6). This absorption peaks existed upon addition of 1 eq. $\mathrm{Cu}^{2+}$ and the further addition of $\mathrm{Cu}^{2+}$ did not change the absorbance spectrum. The color change from colorless to pink could also be detectable by naked eye for the solution 1 along with the addition of $\mathrm{Cu}^{2+}$. Behaviors evolving for compound 1 were similar to those reported $\mathrm{Cu}^{2+}$ cation sensors. A diarylethene-based compound gives absorbance at $344 \mathrm{~nm}$, while its interaction with $\mathrm{Cu}^{2+}$ formed a peak at $412 \mathrm{~nm}$, changing color from colorless to yellow (Liu, Cui, Shi, \& Pu, 2019). A coumarin based compound produces a peak at $335 \mathrm{~nm}$, while its interaction with $\mathrm{Cu}^{2+}$ formed a peak at $418 \mathrm{~nm}$, changing the color from yellow to colorless ( $\mathrm{Li}$ et al., 2019). A benzimidazole-quinoline-based compound (BMQ) results peaks at $342 \mathrm{~nm}$ and $418 \mathrm{~nm}$, while the interaction with $\mathrm{Cu}^{2+}$ forms spectra at $550 \mathrm{~nm}$, changing color from yellow to purple (Liv et al., 2017). 
Alike phenomena of UV-Vis absorption were observed upon addition of $\mathrm{Fe}^{3+}$ and $\mathrm{Cu}^{2+}$ into solution 1. The observed hypsochromic absorption spectral shift might be due to the formation of cation and sensor complex (Takagi, 1990). The hypsochromic shifting which is the shifting of peak to shorter wavelengths, indicating that dipole charge interaction in excited state is greater than that of in ground state. When the cation interacts with a free electron pair donor group, intramolecular charge transfer occurs so that the excited state becomes increasingly unstable. This has an impact on the formation of new absorbance bands on the hypsochromic shift of the UV spectrum.

The new peaks in UV-Vis spectra might be accredited to a metal-to-ligand-charge-transfer (MLCT) which was responsible for the faint yellow and pink colors of the solution 1 upon addition of $\mathrm{Fe}^{3+}$ or $\mathrm{Cu}^{2+}$. Metal complex formation is on enlightenment of the coordination of metal ions with the lone-pair electrons of the nitrogen and oxygen atoms which are known as centers to coordinate with different transition metal ions. After binding with $\mathrm{Fe}^{3+}$ or $\mathrm{Cu}^{2+}$, the charge density in the whole compound 1 changed and transferred thoroughly which will generate new absorption pe aks in the UV-Vis spectra and naked eye color changes (Austin, Chen, \& Rodgers, 2012; Chen et al., 2015; Devarai et al., 2012; Erdemir \& Malkondu, 2015; Janakipriya et al., 2015; Sherman, 1985). Clearly, compound 1 which were bound with metal ions with different charge density $\left(\mathrm{Fe}^{3+}\right.$ and $\left.\mathrm{Cu}^{2+}\right)$ provided different absorption peaks in UV-Vis spectra. Hence, compound 1 was supposed to be an efficient colorimetric sensor to identify $\mathrm{Cu}^{2+}$ and $\mathrm{Fe}^{3+}$ metal ions. Therefore, compound 1 could be named as a chromoionophore, since this compound having electron donors changed its color upon complexation with analytes, in this case is $\mathrm{Fe}^{3+}$ or $\mathrm{Cu}^{2+}$. This study is the first established principle in the development of chromoionophore based on nitrophenyl cynnamaldehide derivative.

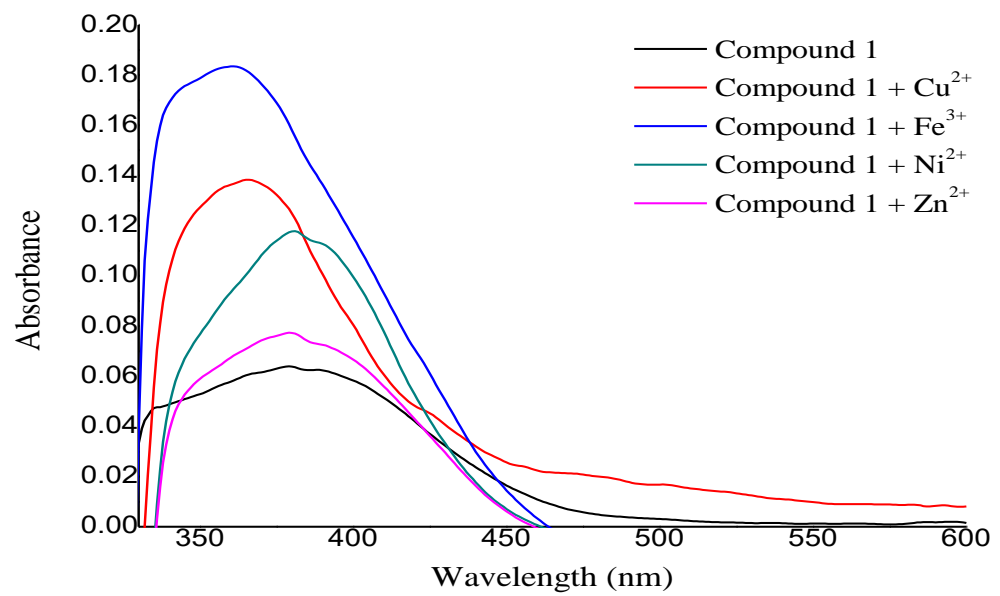

Figure 4. The absorption spectra of compound $1\left(1 \times 10^{-5} \mathrm{M}\right)$ in acetone upon the addition 4 eq. of metal ions solutions.

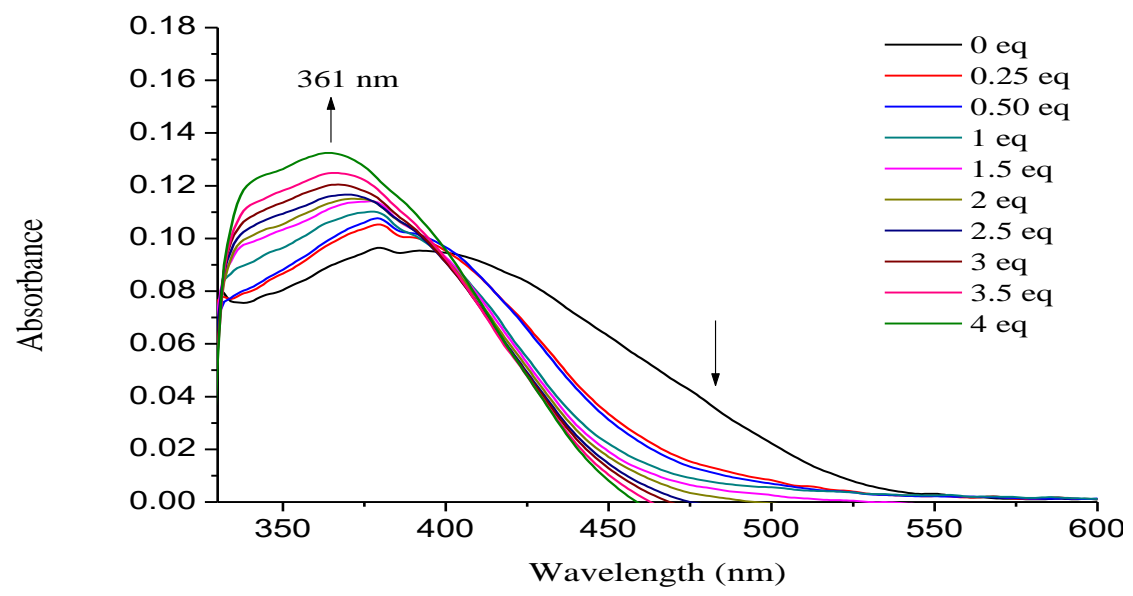

Figure 5. The absorption spectra of compound $1\left(1 \times 10^{-5} \mathrm{M}\right)$ in acetone upon the addition $0-4$ eq. of $\mathrm{Fe}^{3+}$. 


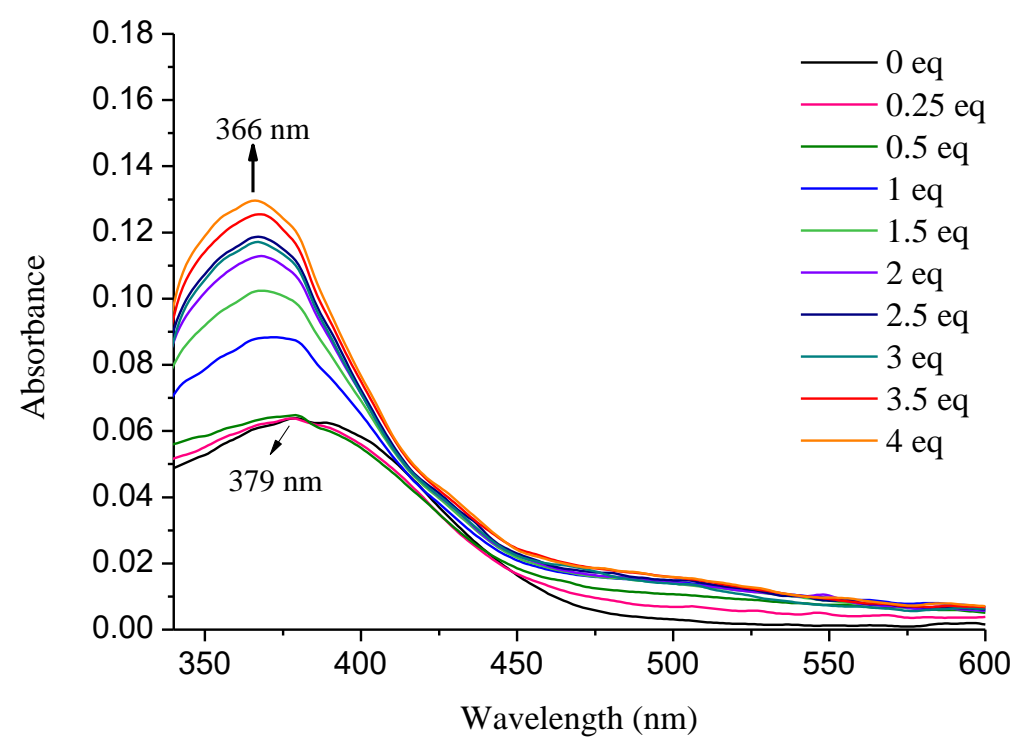

Figure 6. The absorption spectra of compound $1\left(1 \times 10^{-5} \mathrm{M}\right)$ in acetone upon the addition 0-4 eq. of $\mathrm{Cu}^{2+}$.

The calculation formula of limit of detection $(L O D)=$ $3 \mathrm{Sd} / \mathrm{s}$ and limit of quantification $(\mathrm{LOQ})=10 \mathrm{Sd} / \mathrm{s}$, where $\mathrm{Sd}$ and $s$ are the liner curve slope and standard deviation, respectively, were applied (Zou et al., 2015; Saleh et al., 2019). The LOD and LOQ of compound 1 were determined to be $4.19 \times 10^{-5} \mathrm{M}$ and $1.39 \times 10^{-4}$ $\mathrm{M}$ for $\mathrm{Fe}^{2+}$ and $2.66 \times 10^{-5} \mathrm{M}$ and $8.88 \times 10^{-5} \mathrm{M}$ for $\mathrm{Cu}^{2+}$, respectively. The selectivity sensing of compound 1 for $\mathrm{Fe}^{3+}$ and $\mathrm{Cu}^{2+}$ was probably due to the cooperation of combined effects, such as the proper radius, the suitable coordination geometry and charge density of the tested metal ions (Geng, Wang, Zhu, Jiang $\&$ Wang, 2017). Among the tested cations, the order of diameter of cations was $\mathrm{Fe}^{3+}<\mathrm{Cu}^{2+}<\mathrm{Ni}^{2+}<\mathrm{Zn}^{2+}$ (Luo et al., 2011). As the diameter of $\mathrm{Fe}^{3+}$ and $\mathrm{Cu}^{2+}$ are shorter than that of $\mathrm{Ni}^{2+}$ and $\mathrm{Zn}^{2+}$, they provide appropriate radius for electrostatic interactions and undergo complexation reactions with compound 1. Interestingly, the complexation of compound 1 took place at higher concentrations of $\mathrm{Fe}^{3+}$ than that of $\mathrm{Cu}^{2+}$. This was an unexpected result as the $\mathrm{Fe}^{3+}$ has shorter diameter than that of $\mathrm{Cu}^{2+}$ which should has considered greater electrostatic interactions to compound 1. This result can be explained on the basis of charge density and the suitable coordination geometry.

Factors which can affect the coordination bonds between compound 1 with $\mathrm{Fe}^{3+}$ or $\mathrm{Cu}^{2+}$ are the electrostatic repulsion between ligands, the shape of the ligand and metal bonds (Sacconi, 2009). $\mathrm{Fe}^{3+}$ and $\mathrm{Cu}^{2+}$ have $d 5$ and $d 9$ orbitals, respectively. These $d$ orbitals have empty orbitals which allow for $d$ - $d$ transitions with ligand electrons to create energy gaps. The number of electrons involved influences the coordination geometry that will be generated. The possible coordination geometry that can be formed for the complexes of compound 1 and $\mathrm{Fe}^{3+}$ or $\mathrm{Cu}^{2+}$ is tetrahedral or octahedral (Figure 6). In the presence of water, the coordination bonds may include water $\left(\mathrm{H}_{2} \mathrm{O}\right)$ because it has lone pair electrons which can act as a ligand for binding with cations. The complex structure of the compound 1 and $\mathrm{Fe}^{3+}$ or $\mathrm{Cu}^{2+}$ need to be further explore using computer modelling.

b)

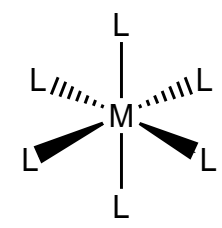

$$
\begin{aligned}
& \mathrm{L}=\text { ligand }\left(\text { Compound } \mathbf{1} \text { or } \mathrm{H}_{2} \mathrm{O}\right) \\
& \mathrm{M}=\text { cation }\left(\mathrm{Fe}^{3+} \text { or } \mathrm{Cu}^{2+}\right)
\end{aligned}
$$

Figure 6. The possible coordination geometry for the complexes of compound 1 and $\mathrm{Fe}^{3+}$ or $\mathrm{Cu}^{2+}:$ (a) tetrahedral or (b) octahedral. 


\section{CONCLUSIONS}

We have developed a novel cation sensor 1 based on organic compound from cynnamaldehide having an aminophenol moiety as a receptor for metal analyte. Sensors 1 were selective for $\mathrm{Cu}^{2}$ and $\mathrm{Fe}^{3+}$ over $\mathrm{Ni}^{2+}$ and $\mathrm{Zn}^{2+}$ ions. A metal-to-ligand-charge-transfer (MLCT) had occurred and the complexation between the cations with the sensor 1 was formed. The subsequent charge density of the sensor changed resulting in the visible color and UV-Vis spectral changes. These results suggested that an organic compound based cinnamaldehyde derivative could provide very important application in cation recognition and sensing of chemical, environmental and biological systems. Further studies using computational methods need to be done for assessing a metal-to-ligand-charge-transfer (MLCT) process and predicting the complexation structure of the cations with the sensor 1. Additionally, the development of chromoionophore based on nitrophenyl cynnamaldehide derivative need to explore further.

\section{ACKNOWLEGMENT}

The authors acknowledge their thanks to Sebelas Maret University for the financial support of this research in the form of Hibah Riset Mandatory (RM-UNS) with contract number 1073/UN27.21/PP/2017.

\section{REFERENCES}

Aderinto, S.O., \& Imhanria, S. (2018). Fluorescent and Colourimetric 1,8-Naphthalimide-appended Chemosensors for the Tracking of Metal lons: Selected Examples from the Year 2010 to 2017. Chemical Papers, 72, 1823-1851. https://doi.org/10.1007/s1 1696-018-0411-0

Ali, H., Khan, E., \& Ilahi, I. (2019). Environmental Chemistry and Ecotoxicology of Hazardous Heavy Metals. Journal of Chemistry, article ID 6730305. https://doi.org/10.1155/2019/6730305

Austin, C.A., Chen, Y., \& Rodgers, M.T. (2012). Alkali Metal Cation-Cyclen Complexes: Effects of Alkali Metal Cation Size on the Structure and Binding Energy. International Journal Mass Spectrometry, 330-332, 27-34. doi: 10.1021/ip502275q

Bansod, B.K., Kumar, T., Thakur, R., Rana, S., \& Singh, I. (2017). A Review on Various Electrochemical Techniques for Heavy Metal lons Detection with Different Sensing Platforms. Biosensensors and Bioelectronics, 94, 443-455. doi: 10.1016/j.bios.2017.03.031

Chen, C., Men, G., Bu, W., Liang, C., Sun, H., \& Jiang, S. (2015). A Colorimetric and Fluorescent Probe for Multiple Transition Metal lons $\mathrm{CCu}^{2+}, \mathrm{Zn}^{2+}$ and $\mathrm{Ni}^{2+}$ ): Fast Response and High Selectivity. Sensors and Actuators B: Chemical, 220, 463-471. https://doi.org/10.1016/i.snb.2015.06.004
Chen, S., Xue, Z., Gao, N., Yang, X., \& Zang, L. (2020). Perylene Diimide-Based Fluorescent and Colorimetric Sensors for Environmental Detection. Sensors, 20(3), 917. doi: $10.3390 / \mathrm{s} 20030917$

Dalmieda, J., \& Kruse, P. (2019). Metal Cation Detection in Drinking Water. Sensors 19(23). 5134 (44 pages). https://doi.org/10.3390/s19235134

Devarai, S., Tsui, Y.-K., Chiang C.-Y., \& Yen, Y.-P. (2012). A New Dual Functional Sensor: Highly Selective Colorimetric Chemosensor for $\mathrm{Fe}^{3+}$ and Fluorescent Sensor for $\mathrm{Mg}^{2+}$. Spectrochimica Acta A: Molecular and Biomolecular Spectroscopy, 96, 594-599. doi: 10.1016/i.saa.2012.07.032

Erdemir, S., \& Malkondu, S. (2015). A Simple Triazolebased "Turn on" Fluorescent Sensor for $\mathrm{Al}^{3+}$ Ion in $\mathrm{MeCN}-\mathrm{H}_{2} \mathrm{O}$ and $\mathrm{F}^{-}$lon in $\mathrm{MeCN}$. Journal of Luminescence, 158, 401-406. doi: 10.1016/i.jlumin.2014.10.043

Geng, T.-M., Wang, X., Zhu, F., Jiang, H., \& Wang, Y. (2017). Sensing of Polymeric Sensor-based Rhodamine B Derivative for Metal Cations in Complete Aqueous Solution. Bulletin of Materials Science, 40(1), 187-193. doi: 10.1007/s12034016-1325-5

Ghule, N.V., Bhosale, R.S., Puyad, A.L., \& Bhosale, S.V. (2016). Naphthalenediimide Amphiphile Based Colorimetric Probe for Recognition of $\mathrm{Cu}^{2+}$ and $\mathrm{Fe}^{3+}$ lons. Sensors and Actuators B: Chemical, 227, https://doi.org/10.1016/i.snb.2015.12.041

Hyalii, R.R., Bhagure, G.R., \& Chavan, R.P. (2017). Development of Electrochemical Sensor for Determination of Lead (II) lon. International Journal of Chemical Studies, 5(3), 745-750.

Jaishankar, M., Tseten, T., Anbalagan, N., Mathew, B.B., \& Beeregowda, K.N. (2014). Toxicity, Mechanism and Health Effects of Some Heavy Metals. Interdisciplinary Toxicology 7(2), 60-72. doi: 10.2478/intox-2014-0009

Janakipriya, S., Chereddy, N. R., Korrapati, P., Thennarasu, S., \& Mandal, A.B. (2016). Selective Interactions of Trivalent Cations $\mathrm{Fe}^{3+}, \mathrm{Al}^{3+}$ and $\mathrm{Cr}^{3+}$ Turn on Fluorescence in a Naphthalimide Based Single Molecular Probe. Spectrochimica Acta A: Molecular and Biomolecular Spectroscopy, 153, 465-470. doi: 10.1016/i.saa.2015.08.044

Kaur, N., \& Kumar, S. (2011). Colorimetric Metal lon Sensors. Tetrahedron, 67(48), 9233-9264. https://doi.org/10.1016/j.tet.2011.09.003

Kumar, S., Mittal, S.K., Kaur N., \& Kau, R. (2017). Improved Performance of Schiff Based lonophore Modified with MWCNT for Fe (II) Sensing by Potentiometry and Voltammetry Supported with 
DFT Studies. RSC Advances. 7, 16474-16483. https://doi.org/10.1039/C7RA00393E

Lee, S.Y., Yang M., \& Kim, C. (2018). A Dual Target Chemosensor for the Fluorometric Detection of $\mathrm{In}^{3+}$ and Colorimetric Detection of $\mathrm{Fe}^{3+}$. Spectrochimica Acta A: Molecular and Biomolecular Spectroscopy, 205, 622-629. doi: 10.1016/i.saa.2018.07.091

Li, H., Sun, X., Zheng, T., Xu, Z., Song, Y. \& Gu, X. (2019). Coumarin-based Multifunctional Chemosensor for Arginine/Lysine and $\mathrm{Cu}^{2+} / \mathrm{Al}^{3+}$ lons and Its $\mathrm{Cu}^{2+}$ Complex as Colorimetric and Fluorescent Sensor for Biothiols. Sensors and Actuators B: Chemical, 279, 400-409. DOI: 10.1016/i.snb.2018.10.017

Liu, H., Cui, S., Shi, F., \& Pu, S. (2019). A Diarylethene Based Multi-Functional Sensor for Fluorescent Detection of $\mathrm{Cd}^{2+}$ and Colorimetric Detection of $\mathrm{Cu}^{2+}$. Dyes Pigments, 161, 34-43. https://doi.org/10.1016/i.dyepig.2018.09.030

Liu, L., Dan, F., Liu, W., Lu, X., Han, Y., Xiao, S., \& Lan, H. (2017). A High Contrast Colorimetric and Fluorescent Probe for $\mathrm{Cu}^{2+}$ Based on Benzimidazolequinoline. Sensors and Actuators B: Chemical, 247, 445-450. doi: 10.1016/ i.snb.2017.03.069

Momidi, B.K., Tekuri, V., \& Triveti, D.R. (2017). Multisignaling Thiocarbohydrazide Based Colorimetric Sensors for the Selective Recognition of Heavy Metal lons in an Aqueous Medium. Spectrochimica Acta A: Molecular and Biomolecular Spectroscopy, 180, 175-182. DOI: 10.1016/i.saa.2017.03.010

Luo, J., Jiang, S., Qin, S., Wu, H., Wang, Y., Jiang, J., \& Liu, X.Y. (2011). Highly Sensitive and Selective Turn-on Fluorescent Chemosensor for $\mathrm{Hg}^{2+}$ in Pure Water Based on a Rhodamine Containing Water-soluble Copolymer. Sensors and Actuators B: Chemical, 160, 1191-1197. https://doi.org/10.1016/i.snb.2011.09.047

March, G.; Nguyen, T.D., \& Piro, B. (2015). Modified Electrodes Used for Electrochemical Detection of Metal lons in Environmental Analysis. Biosensors, 5(2), 241-275. https://doi.org/10.3390/ bios5020241

Normaya, E., Syuhada, R., Ismail, H., Ahmad, M.N., Yarmob, M.A., \& Bulatc, K.H.K. (2019). Chemosensor Development of $\mathrm{Cu}^{2+}$ Recognition Using 1,5-Diphenylthiocarbazone: Optimization, COSMO-RS and DFT Studies. Journal of the Brazilian Chemical Society, 30(9), 1850-1859.

Peralta-Domínguez, D., Rodríguez, M., Ramos-Ortíz, G., Maldonado, J.L., Meneses-Nava, M.A., Barbosa-García, O., Santillan, R., \& Farfán, N. (2015). A Schiff Base Derivative from
Cinnamaldehyde for Colorimetric Detection of $\mathrm{Ni}^{2+}$ in Water. Sensors and Actuators B: Chemical, 207, 511-517.

Pham, T.C., Kim, Y.K., Park, J.B., Jeon, S., Ahn, J., Yim, Y., Yoon, J. \& Lee, S. (2019). A Selective Colorimetric and Fluorometric Chemosensor Based on Conjugated Polydiacetylenes for Cadmium Ion Detection. ChemPhotoChem, 3(11), 1133-1137. https://doi.org/10.1002/cptc.201900165

Sacconi, L., (2009). Five coordination in 3d metal complexes. Pure Applied Chemistry, 17(1), 95$128 . \quad$ doi: https://doi.org/10.1351/ pac196817010095

Saleh, S.M., Ali, R., Alminderej, F., Ali, I.A.I. (2019). Ultrasensitive Optical Chemosensor for $\mathrm{Cu}(\mathrm{II})$ Detection. International Journal of Analytical Chemistry, 2019, 7381046. doi:10.1155/2019/ 7381046.

Sherman, D.M. (1985). The Electronic Structures of $\mathrm{Fe}^{3+}$ Coordination Sites in Iron Oxides: Application to Spectra, Bonding and Magnetism. Physics and Chemistry of Minerals. 12, 161-175. https://doi.org/10.1007/BF00308210.

Suryanti, V., Bhadbhade, M., Chawla, H.M., Howe, E., Thordarson, P., Black. D.StC., \& Kumar, N. (2014). Novel Colorimetric Anion Sensors Based on $\mathrm{N}$-acetylglyoxylic Amides Containing Nitrophenyl Signaling Units. Spectrochimica Acta A: Molecular and Biomolecular Spectroscopy, 121, 662-669. https://doi.org/10.1016/ i.saa.2013.11.108.

Suryanti, V., Wibowo, F.R., Pranoto, Isnaeni, S.R., Sari, M.R.K., \& Handayani, S. (2016). Addition Reaction of Methyl Cinnamate with 2-Amino-4Nitrophenol. IOP Conferences Series: Materials Science and Engineering, 107, 012062. doi:10.1088/1757-899X/107/1/012062.

Suryanti, V., Bhadbhade, M., Black, D.StC., \& Kumar, N. (2017). N-acetylglyoxylic Amide Bearing a Nitrophenyl Group as Anion Receptors: NMR and $X$-ray Investigations on Anion Binding and selectivity. Journal of Molecular Structure, 1146 , 571-576. https://doi.org/10.1016/j.molstruc. 2017.05.133.

Suryanti, V., Wibowo, F.R., \& Handayani, S. (2020). Methyl-3-(2-hydroxy-5-nitrophenyl amino)-3phenylpropanoate Based Colorimetric Sensor for Oxyanions. Indonesia Journal of Chemistry, 20(2), 257-263. doi: 10.22146/ijc.39559.

Takagi, M. (1990). Cation Binding by Macrocycles. Eds. Inove, Y.; Gokel, G. W.; Dekker, New York, 465.

Tchounwou, P.B., Yedjou, C.G., Patlolla, A.K., \& Sutton, D.J. (2012). Heavy Metal Toxicity and the Environment. Molecular, Clinical and 
Molekul, Vol. 15. No. 3, November 2020: $191-198$

Environmental Toxicology, 101, 133-164. doi: 10.1007/978-3-7643-8340-4 6.

Topcu, C., Lacin, G., Yilmaz, V., Coldur, F., Caglar, B., Cubuk, O., \& Isildak, I. (2018). Electrochemical Determination of Copper (II) in Water Samples Using a Novel lon-Selective Electrode Based on a Graphite Oxide-Imprinted Polymer Composite. Analytical Letters, 51(12), 1890-1910. https://doi.org/10.1080/00032719.2017.1395 035

Upadhyay, S., Singh, A., Sinha, R., Omer, S., \& Negi, K. (2019). Colorimetric Chemosensors for d-Metal lons: A Review in the Past, Present and Future Prospect. Journal of Molecular Structure, 1193, 89-102. doi: 10.1016/j.molstruc.2019.05.007

Zou, L., Yan, B., Pan, D., Tan, Z., Bao, X. (2015). A colorimetric and absorption ratiometric anion sensor based on indole \& hydrazide binding units. Spectrochimica Acta Part A: Molecular Spectroscopy. 148:78-84. doi: 10.1016/i.saa. 2015.03.109.

Wang, L., Fang, G., \& Cao, D. (2015). A Novel Phenolbased BODIPY Chemosensor for Selective Detection $\mathrm{Fe}^{3+}$ with Colorimetric and Fluorometric Dual-Mode. Sensors and Actuators B: Chemical, 207, 849-857. DOI: 10.1016/j.snb. 2014.10.110.

Wang, M., Leung, K-H., Lin, S., Chan, D.S-H., Kwong, D.W.J., Leung, C-H., \& Ma, D-L. (2015). A Colorimetric Chemosensor for $\mathrm{Cu}^{2+}$ lon Detection Based on an Iridium (III) Complex. Scientific Reports, 4, Article number: 6794. doi: 10.1038/srep06794. 